\title{
Determination of genes and microRNAs involved in the resistance to fludarabine in vivo in chronic lymphocytic leukemia
}

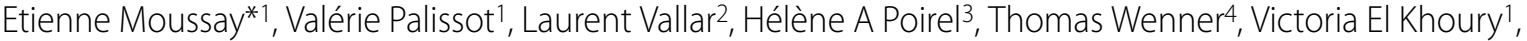 \\ Nasséra Aouali1 , Kris Van Moer1, Bernadette Leners'1, François Bernardin², Arnaud Muller², Pascale Cornillet-Lefebvre5, \\ Alain Delmer ${ }^{5}$, Caroline Duhem ${ }^{6}$, Fernand Ries ${ }^{6}$, Eric van Dyck and Guy Berchem¹,6
}

\begin{abstract}
Background: Chronic lymphocytic leukemia (CLL) cells are often affected by genomic aberrations targeting key regulatory genes. Although fludarabine is the standard first line therapy to treat $C L L$, only few data are available about the resistance of $B$ cells to this purine nucleoside analog in vivo. Here we sought to increase our understanding of fludarabine action and describe the mechanisms leading to resistance in vivo. We performed an analysis of genomic aberrations, gene expression profiles, and microRNAs expression in CLL blood B lymphocytes isolated during the course of patients' treatment with fludarabine.

Results: In sensitive patients, the differentially expressed genes we identified were mainly involved in p53 signaling, DNA damage response, cell cycle and cell death. In resistant patients, uncommon genomic abnormalities were observed and the resistance toward fludarabine could be characterized based on the expression profiles of genes implicated in lymphocyte proliferation, DNA repair, and cell growth and survival. Of particular interest in some patients was the amplification of MYC (8q) observed both at the gene and transcript levels, together with alterations of myctranscriptional targets, including genes and miRNAs involved in the regulation of cell cycle and proliferation. Differential expression of the sulfatase SULF2 and of miR-29a, -181a, and -221 was also observed between resistant and sensitive patients before treatment. These observations were further confirmed on a validation cohort of CLL patients treated with fludarabine in vitro.

Conclusion: In the present study we identified genes and miRNAs that may predict clinical resistance of CLL to fludarabine, and describe an interesting oncogenic mechanism in CLL patients resistant to fludarabine by which the complete MYC-specific regulatory network was altered (DNA and RNA levels, and transcriptional targets). These results should prove useful for understanding and overcoming refractoriness to fludarabine and also for predicting the clinical outcome of CLL patients before or early during their treatment.
\end{abstract}

\section{Background}

Chronic lymphocytic leukemia (CLL), the most common hematologic malignancy in Western countries, is characterized by the accumulation in the blood of monoclonal $\mathrm{CD}^{+} \mathrm{CD} 19^{+} \mathrm{CD} 23^{+} \mathrm{B}$ lymphocytes mainly arrested in $\mathrm{G}_{0} / \mathrm{G}_{1}$ phase of the cell cycle. Various cytogenetic abnormalities are often found in CLL B cells. Importantly, a few

*Correspondence: etienne.moussay@crp-sante.lu, berchem.guy@chl.lu 1 Laboratory of Experimental Hemato-Oncology, CRP-Santé, Luxembourg, Luxembourg

${ }^{6}$ Centre Hospitalier de Luxembourg, Luxembourg, Luxembourg Full list of author information is available at the end of the article conserved aberrations are consistently observed in association with rapid disease progression and short survival times [1]. These aberrations affect chromosome 12 (trisomy), 13q14 (microRNA-15a (miR-15a)/miR-16-1), 17p13 (TP53) and 11q22 (ATM). CLL B cells fail to fulfill their immunological role and are not able to achieve either their final differentiation or programmed cell death.

Due to their potential to kill non-dividing cells [2], purine nucleoside analogs such as fludarabine (9-b-Darabinofuranosyl-2-fluoroadenine) are often used as first- 
line therapy to prolong the progression-free survival of CLL patients. In addition to the use of fludarabine as a single chemotherapeutic agent, new attractive therapies combining fludarabine with chimeric monoclonal antibodies were recently successfully introduced.

The mechanisms underlying the toxic effects of fludarabine have been studied in vitro. In proliferating cells, fludarabine requires DNA synthesis for cytotoxicity and induces apoptosis in a cell cycle-dependent manner by inhibiting several enzymes involved in DNA metabolism [3]. In quiescent human lymphocytes, fludarabine incorporation inhibits DNA synthesis during DNA repair and thus induces irreversible damage triggering disruption of mitochondrial integrity and apoptosis $[4,5]$. The p53 signaling pathway, which provides a major control mechanism to regulate cell cycle arrest and apoptosis in response to DNA damage, is also involved in fludarabinemediated cytotoxicity. Post-translational modifications of p53 regulate its activity and determine cell fate by modulating the class of target genes inducing $G_{1}$ or $G_{2}$ arrest, DNA repair and/or apoptosis depending on the extent and severity of damages [6]. Killing of resting lymphocytes was previously reported to act by p53-independent and -dependent manners in vitro and in vivo [2]. In addition to p53-related aspects, the resistance to cancer treatment in CLL has been connected to biochemical alterations targeting membrane transporters, deoxycytidine kinase, and cytoplasmic 5'-nucleotidase $\mathrm{cN}$-II activities, and more recently to changes in the levels of miR34a [7], a miRNA belonging to the class of small non-coding RNA molecules mediating post-transcriptional gene silencing. MicroRNAs regulation is currently the subject of intense research, and differential expression of miRNAs has been reported in B cells of healthy donors and CLL patients [7-10].

Previous in vitro studies of fludarabine were based on the treatment of cells in culture and did not take in consideration parameters like pharmacokinetics and cell microenvironment which represent critical factors for the outcome of the treatment in vivo. Although fludarabine has been known for twenty years to have considerable activity against CLL [11], its mode of action at the molecular level in vivo is only poorly described. Thus, half the cases of resistance that manifest after several rounds of fludarabine treatment [12] cannot be explained by p53 defects [13]. In this study, we have addressed the response of CLL B cells to fludarabine in vivo. We have investigated the mechanisms involved in the resistance to fludarabine and identified molecular markers predictive of poor clinical responses. Rare genomic aberrations were detected that target genes playing prominent roles in the regulation of important cellular mechanisms. We report on a set of genes and miRNAs that could predict the clinical outcome of CLL patients and refine prognosis before che- motherapeutic treatment. Finally, we discuss the perspectives offered by our findings for improving CLL therapeutic strategies, overcoming resistance in CLL patients and enhancing the overall survival of previously treated patients with impaired prognosis.

\section{Methods \\ Patients and samples}

This research was approved by the Comité National d'Ethique de Recherche (Luxembourg, №200509/05) and participants gave written informed consent in accordance with the Declaration of Helsinki. CLL was diagnosed according to standard clinical and laboratory criteria. Patients received fludarabine $\left(25 \mathrm{mg} / \mathrm{m}^{2}\right.$ for 5 days per cycle, Fludara', Bayer Healthcare Pharmaceuticals) during their therapy in the departments of hematology/ oncology (Centre Hospitalier du Luxembourg and University Hospital of Reims). Clinical details, previous treatments and genomic characteristics of patients $(\mathrm{N}=18$, CLL-1 to -18) are summarized in Additional file 1. CLL patients showing an important decrease in lymphocyte count after treatment and not requiring further therapy were classified as sensitive (called S) to fludarabine. Other patients were classified as refractory to the treatment (called R) as they showed only a moderate decrease of their lymphocyte count after treatment, relapsed very quickly, and required further therapies. Patient CLL-3R died because of CLL complications two months after the beginning of the treatment. The treatment of patient CLL-2S was stopped because of a cytomegalovirus reactivation. In addition, a validation cohort of CLL patients $(\mathrm{N}=21, \mathrm{CLL}-19$ to -39$)$ was used to confirm the prognostic role of genes and miRNAs on the evaluation of the resistance to fludarabine in vitro.

Peripheral blood samples were collected from patients before their treatment (T0) for patients CLL-1 to -18 , and after 1 to 9 days of fludarabine treatment in vivo (T1, T2, and T9, for patients CLL-1 to -6 only), and from CLL patients recruited for the in vitro validation (CLL-19 to 39). The isolation of mononuclear cells was performed from whole blood by density gradient centrifugation using the Lympho isolation medium (MP Biomedicals, France). From the collected cells, the proportion of B cells was always greater than $90 \%$. Otherwise, a negative selection was performed to eliminate $\mathrm{T}$ and NK cells and monocytes/macrophages with help of the Dynabeads ${ }^{\circ} \mathrm{CD} 2$ and CD14 (Dynal Biotech, Norway), respectively.

\section{Cytotoxicity assay}

Cell viability was measured by using the tetrazolium saltbased Cell Counting Kit-8 assay (Dojindo Molecular Technologies, Inc., Eke, Belgium). Cells from patients CLL-19 to -39 were washed twice in PBS and cultured at 
a density of $1.5 \times 10^{6} / \mathrm{ml}(100 \mu \mathrm{l}$ per well in 96 -well plates $)$ in RPMI-1640 supplemented with $10 \%$ of fetal calf serum. Cells were treated for $48 \mathrm{~h}$ with a range of fludarabine (Fludara ${ }^{\circ}$ Bayer Healthcare) concentrations $(0-10 \mu \mathrm{M})$, including clinically achievable concentrations (1.5 - 4.5 $\mu \mathrm{M},[14])$. CCK-8 reagent was then added and plates were incubated before measuring the absorbance at $450 \mathrm{~nm}$.

\section{DNA isolation, array-based CGH, cytogenetics, and FISH analyses}

All genetic analyses were performed on sample T0 prior to treatment. Comparative Genomic Hybridization $(\mathrm{CGH})$ array analysis was performed to identify genomic aberrations in B cells of patients CLL- 1 to -6 only. Briefly, DNA of selected B cells was isolated using the QIAamp DNA Blood Mini Kit (QIAGEN) following the instructions of the manufacturer. After enzymatic digestion (AluI and RsaI), $2 \mu \mathrm{g}$ of patient DNA and control Human Genomic DNA (Promega) were coupled with the Genomic DNA Labeling Kit PLUS (Agilent, France) to cyanine 5 and 3, respectively, and then hybridized ( $40 \mathrm{~h}$ at $65^{\circ} \mathrm{C}$ ) on Agilent 60-mer $244 \mathrm{~K}$ Human Genome CGH Microarray following protocols of the manufacturer. Images were analyzed with Feature Extraction software (Agilent) and data analysis was performed with CGHAnalytics (Agilent) using the Aberration Detection Methods ADM1 and ADM2.

Conventional cytogenetic analyses were available for patients CLL- 1 to -18 . Fluorescence in situ hybridization (FISH) analysis was performed using the LSI ATM-2/ CEP11, LSI p53/CEP17, LSI S13S319 with CEP 12, LSI IGH/BCL2, LSI IGH/CCND1 and LSI PML/RARA fluorescent probes (Vysis/Abbott, Belgium) according to standard protocols.

\section{RNA isolation}

The procedure followed was similar for cells from patients treated in vivo and cells incubated in vitro. The B cells were centrifuged at $350 \mathrm{~g}$ for $5 \mathrm{~min}$ at $20^{\circ} \mathrm{C}$ and the pellet was lysed in Trizol $^{\circ}$ (Invitrogen) following the instructions of the manufacturer with slight modifications. Briefly, after addition of chloroform and vigorous shaking, the samples were transferred into $1.5 \mathrm{ml}$-Phase Lock Gel Heavy tubes (Eppendorf) and centrifuged for 10 $\min \left(12,000 \mathrm{~g}\right.$ at $\left.4^{\circ} \mathrm{C}\right)$. The aqueous phase was recovered and $5 \mu \mathrm{g}$ of RNase-free glycogen were added as carrier. Total RNA was precipitated with isopropyl alcohol overnight at $-20^{\circ} \mathrm{C}$, centrifuged at $12,000 \mathrm{~g}$ for $10 \mathrm{~min}$ at $4^{\circ} \mathrm{C}$, and washed once with $75 \%$ ethanol. After treatment with DNase (DNA-free ${ }^{\mathrm{Tm}}$, Ambion), RNA quantity and quality were evaluated with the NanoDrop ND-1000 spectrophotometer and the Agilent 2100 bioanalyzer, respectively.
TP53 and Immunoglobulin heavy-chain sequence analysis We analyzed DNA samples from CLL patients by PCR and fluorescent sequencing to determine TP53 mutational status (exon 2-10) using Big Dye Terminator kit and ABI 3130 sequencer (Applied Biosystems). The primer sequences are available upon request.

The B lymphocyte Ig gene rearrangement and mutational status was determined by IgVH-specific RT-PCR and sequencing [15]. Complementary DNA (cDNA) was obtained by reverse transcription of $2 \mu \mathrm{g}$ RNA by using the Reverse Transcriptase Core kit with random nonamers (Eurogentec, Belgium). Fifteen microliters of cDNA were amplified by PCR using a mixture of primers [15] specific for VH1-VH6 sequences together with either a 3' primer specific for the $\mathrm{JH}$ consensus region or a 3 ' primer specific for the constant region of the IgM locus. Amplification products were gel-extracted and sequenced. Nucleotide sequences were compared to the international ImMunoGeneTics information system (IMGT/VQUEST) and to the NCBI Ig BLAST databases. The homology of the sequence with the closest germline counterpart was assessed and sequences with $98 \%$ or greater homology to germline-encoded $\mathrm{VH}$ gene were categorized as unmutated.

\section{Complementary DNA microarrays}

Microarray experiments were performed with samples from CLL patients sensitive (CLL-1, -2, -4, -5) and resistant (CLL-3 and -6) to fludarabine. As the treatment of patients can be assimilated to a time course experiment, the commonly used two-channel microarray experiment loop design was chosen [16]. Each sample was hybridized to two different samples in two different dye orientations (T0 vs T1, T1 vs T2, T2 vs T9, T9 vs T0) in quadruplicates. Briefly, $1 \mu \mathrm{g}$ of total RNA from B cells of patients CLL-1 to -6 only was amplified and labeled with the Amino Allyl MessageAmp ${ }^{\mathrm{TM}}$ II aRNA Amplification Kit (Ambion, UK). The coupling reaction was performed following the protocol of the manufacturer using Alexa Fluor Reactive Dye Decapacks (AF555 and 647, Molecular Probes). Alexa Fluor-aRNA were hybridized for $16 \mathrm{~h}$ on cDNA microarrays (Operon human version2 oligonucleotide library, University Medical Center Utrecht, The Netherlands). Microarrays were scanned at $10-\mu \mathrm{m}$ resolution with two laser channels (532 and $635 \mathrm{~nm}$ ) using a GenePix 4000B scanner and GenePix Pro 6.0 (Molecular Devices Corporation, CA) at variable photomultiplier tube (PMT) gains (<1\% saturated spots).

Microarray data were deposited in the EMBL-EBI ArrayExpress public repository (Accession number EMTAB-70). The image analysis and spot selection were performed with MAIA 2.7 (Institut Curie, France) as previously described [17]. Acuity 4.0 (Molecular Devices, 
CA) was used for data processing (dye-swap, Lowess normalization), warehousing and visualization. A few microarrays were excluded from analysis based on the results of Pearson cross-correlation coefficient (data not shown). Data were subjected to statistical examination with the SAM add-on for Microsoft Excel (Significance Analysis of Microarrays, Stanford, CA; using centered median, 100 permutations). Missing values were imputed using the $k$-nearest neighbor method $(k=10)$. Delta values were adjusted to obtain gene lists with a false discovery rate $(\mathrm{FDR}) \leq 1 \%$ for one-class analysis and $\leq 5 \%$ for two-class analysis. Genes identified by SAM two-class analysis as regulated in CLL B cells after $24 \mathrm{~h}$ of treatment with fludarabine in vivo were classified by enriched gene sets with the Gene Set Enrichment Analysis algorithm (GSEA 2.05, database Dec 2009; Broad Institute, MA). Differentially regulated genes were clustered as molecular interaction networks with Ingenuity Pathway Analysis (IPA 8.0, database Nov 2009; Ingenuity Systems, CA).

\section{Quantitative RT-PCR}

For validation of microarray data, specific primers were purchased from Eurogentec (primer sequences available upon request). Five nanograms of cDNA were used in a $25 \mu \mathrm{l}$ PCR reaction mixture containing $12.5 \mu \mathrm{l} \mathrm{SYBR}{ }^{\circ}$ Green PCR MasterMix, and $300 \mathrm{nM}$ of each primer. PCR amplifications were performed on ABI 7300 Real-Time PCR System $\left(40\right.$ cycles at $95^{\circ} \mathrm{C}-15 \mathrm{sec}$ and at $60^{\circ} \mathrm{C}-60$ $\mathrm{sec})$. Values were normalized according to previous recommendations [18] to both $28 S$ rRNA and FLOT2 by using the average $\mathrm{Ct}$ value of housekeeping genes and were processed by using the $\mathrm{Ct}$ value obtained before treatment as calibrator (2- $\Delta \mathrm{Ct}$ calculation method).
MicroRNAs to be tested were chosen as i) they were reported as regulated in CLL ii) they modulate genes involved in apoptosis and cell cycle iii) they are known transcriptional targets of Myc. The detection of miRNAs was performed by TaqMan'-based qPCR by using $50 \mathrm{ng}$ of total RNA as starting material. The TaqMan miRNA Reverse Transcription and TaqMan 2X Universal PCR Master Mix, No AmpErase UNG together with specific TaqMan miRNA Assays (all Applied Biosystems) were used for RT and PCR reactions $\left(35\right.$ cycles at $95^{\circ} \mathrm{C}-15 \mathrm{sec}$ and at $60^{\circ} \mathrm{C}-60 \mathrm{sec}$ ). All miRNA expression values were normalized to both $18 S$ rRNA and FLOT2 (2- $\triangle \Delta \mathrm{Ct}$ calculation method). ZAP-70 and LPL quantification were performed as described before [19].

\section{Results}

\section{Common genomic abnormalities observed before} fludarabine treatment

Eighteen CLL patients were given one to six fludarabine cycles ( $25 \mathrm{mg} / \mathrm{m} 2$ per day for 5 days) and classified as sensitive or resistant to the treatment based on changes in lymphocyte counts, relapse, and requirement for further therapy. We first analyzed common genomic abnormalities in samples collected prior to treatment. Results obtained by array-based CGH analysis and targeted genes are presented in Table 1 and Additional file 1. Classical abnormalities affecting 13q14, 11q22, chr 12, and 17p13 were detected. Sequencing of TP53 gene indicated the presence of a V274G point mutation in the exon 8 of $\mathrm{B}$ cells from patient CLL-5S. In patient CLL-3R, a 2nt-deletion in exon 7 induced the presence of a stop at codon 239 (truncated protein). In patient CLL-6R, although one allele was deleted, the second one did not present any

Table 1: Genomic aberrations and targeted genes observed in CLL patients resistant to fludarabine.

\begin{tabular}{|c|c|c|}
\hline Genomic aberrations & Type of aberration & Targeted gene(s) \\
\hline \multirow[t]{2}{*}{$\operatorname{idic}(3 q)$} & Deletion $3 p$ & $X P C, R A D 18, P C A F$ \\
\hline & Gain 3q & BCL6, FAIM, p63 \\
\hline $7 q 21,7 q 36^{1}$ & Gain & MDR family genes \\
\hline \multirow[t]{2}{*}{$\operatorname{idic}(8 q)$} & Deletion 8p & TNFRSF10 family genes \\
\hline & Gain 8q & $M Y C$ \\
\hline $9 p 24 p 212$ & Deletion & $J A K 2, p 16 I N K 4, C D K N 2 B$, SMARCA2 \\
\hline $11 q 23$ & Deletion & ATM \\
\hline $12 p 13.31 p 12$ & Deletion & $p 27$ \\
\hline $13 q 14.2 q 14.3$ & Deletion & $D L E U$ genes, $R b$, miR-15a, miR-16-1 \\
\hline $15 q 15 q 26$ & Gain & $M G A, P M L, B L M$, cyclin $B 2$, and $53 B P 1$ \\
\hline \multirow[t]{2}{*}{$\operatorname{idic}(17 q)$} & Deletion 17p & $p 53, M N T$ \\
\hline & Gain 17q & STAT3, SPOP, RAD51L3, RARA, RDM1 \\
\hline
\end{tabular}

\footnotetext{
1 These aberrations were observed only in patient CLL-6R
}

2 This aberration was observed only in patient CLL-3R 
mutation (Additional file 1). Interestingly, among the ten patients clinically resistant to fludarabine, five (50\%) presented with wild-type TP53 gene, underlying the importance of factors other than p53 in the mechanisms leading to resistance to this drug. In addition, no influence of ZAP-70 expression, IgVH status or deletions affecting $11 \mathrm{q}$ or $13 \mathrm{q}$ on the response to treatment could be identified. In summary, no difference was observed between patients in regards to their sensitivity or resistance to the treatment when taking in consideration classic clinical parameters and history of previous treatments.

\section{Genetic complexity of resistant CLL B cells before fludarabine treatment}

Although the B cells from most patients displayed genomic imbalances (Additional file 1), conventional cytogenetics and $\mathrm{CGH}$-arrays indicated that the extent and complexity of these chromosomal aberrations were higher in B cells from the resistant patients, as illustrated by the losses, gains, and dicentric isochromosomes (idic(17)(p12) and idic(8)(p12) observed in patients CLL$3 R$ and CLL-6R. Thus, a gain on 15q15.1q26.3, where the genes $M G A, P M L, B L M$, cyclin B2, and 53BP1 are located (Table 1), was detected in both patients by CGH and confirmed by FISH analysis (Additional files 2 and 3). We also identified a deletion of 9p24.3p13.1 targeting $J A K 2$, the tumor suppressors $C D K N 2 A$ and $C D K N 2 B$ and SMARCA2 $(\mathrm{Brm})$ in patient CLL-3R. Finally, deletions on 6q14.1q14.3, 14q24.2q24.3 and 14q32.11q32.12 and alterations on chromosome 7 ( $M D R$ genes) rarely observed in CLL were also detected in B cells of patients CLL-3R and $-6 R$, respectively.

\section{Gene expression profile in CLL B cells in response to fludarabine treatment in vivo}

To gain more knowledge about the mechanisms underlying the cellular response to fludarabine, we next examined changes in gene expression profiles induced by fludarabine in vivo. To this end, we identified genes whose expression was altered by fludarabine in B cells from six patients given a fludarabine cycle (5 days). Samples were collected prior to treatment as well as 1,2 and 9 days following the first administration. A one-class SAM analysis was run to specify differentially expressed genes in each patient and time transition in response to the treatment. The four sensitive patients responded similarly to the treatment at all time points. In addition, the responses after $24 / 48 \mathrm{~h}$ of treatment were very similar. Fludarabine-regulated genes $(\mathrm{FDR} \leq 1 \%)$ together with their biological function and fold changes are listed in the Additional file 4. Pathway analysis indicated that most of genes identified in this study as regulated were involved in programmed cell death, cell cycle, p53 signaling, cell stress response, response to DNA damage, and cell-to cell signaling and interaction ( $\mathrm{p}<0.05$, data not shown), confirming previous studies $[4,5,15,20]$. Therefore we focused our investigations on these biological pathways. We noted that most of regulated genes were p53 or Myc transcriptional targets. Therefore a molecular interaction network centered on both transcription factors was created with the most regulated genes after $24 \mathrm{~h}$ of fludarabine treatment in vivo (Fig. 1A). Interestingly, the p53 response was highly induced (dark red) by fludarabine as indicated by the strong up-regulation of $p 21, P L K 2$, cyclin $G 1, D D B 2$, and $X P C$, consistent with the notion that $\mathrm{p} 53$ signaling provides an important pathway leading to cell cycle arrest and cell death in response to fludarabine. Regulators targeting p53 for degradation and important cell growth regulators were also over-expressed after 24/ $48 \mathrm{~h}$ of treatment. On the other hand, a strong down-regulation of several genes was induced by the treatment in all sensitive patients (dark green). Among these were genes regulated by the $M Y C$ and STAT1 transcription factors involved in cell survival (XIAP and BIRC5/survivin), cell growth and proliferation (IL7, IL7R), and DNA repair and replication. Lymphoid markers, chemokines, cytokines, and their receptors were also down-regulated.

A more detailed list of regulated genes and functions can be found in the Additional file 4 .

After 9 days of treatment, a different molecular response was observed; most p53-target genes were now down-regulated, whereas other genes involved in the control of growth and apoptosis were still up-regulated (data not shown).

\section{Gene expression profile in resistant CLL B cells in vivo SAM one-class analysis}

An overlay of gene expression data obtained in cells of resistant patients was performed on the molecular interaction network built with gene expression of sensitive patients. We observed strikingly different molecular responses as few p53-target genes were regulated in cells of resistant patients (Fig. 1B). In contrast, other genes were regulated by MYC and p53 in B cells of resistant CLL patients (Fig. 2A). The conserved families of PI3K and 14-3-3 proteins were highly regulated in B cells of resistant patients together with cell cycle and cell death/ survival regulators. Genes significantly regulated in resistant patients were also involved in nucleoside and nucleotide metabolism (UMPS), the response to DNA damage (PARP1) and replication (MCM7), in contrast to what observed in cells of sensitive patients (Fig. 2B). A more detailed list of regulated genes and functions can be found in the Additional file 5.

\section{SAM two-class analysis}

A direct comparison of the responses elicited by fludarabine in CLL B cells from sensitive and resistant patients 

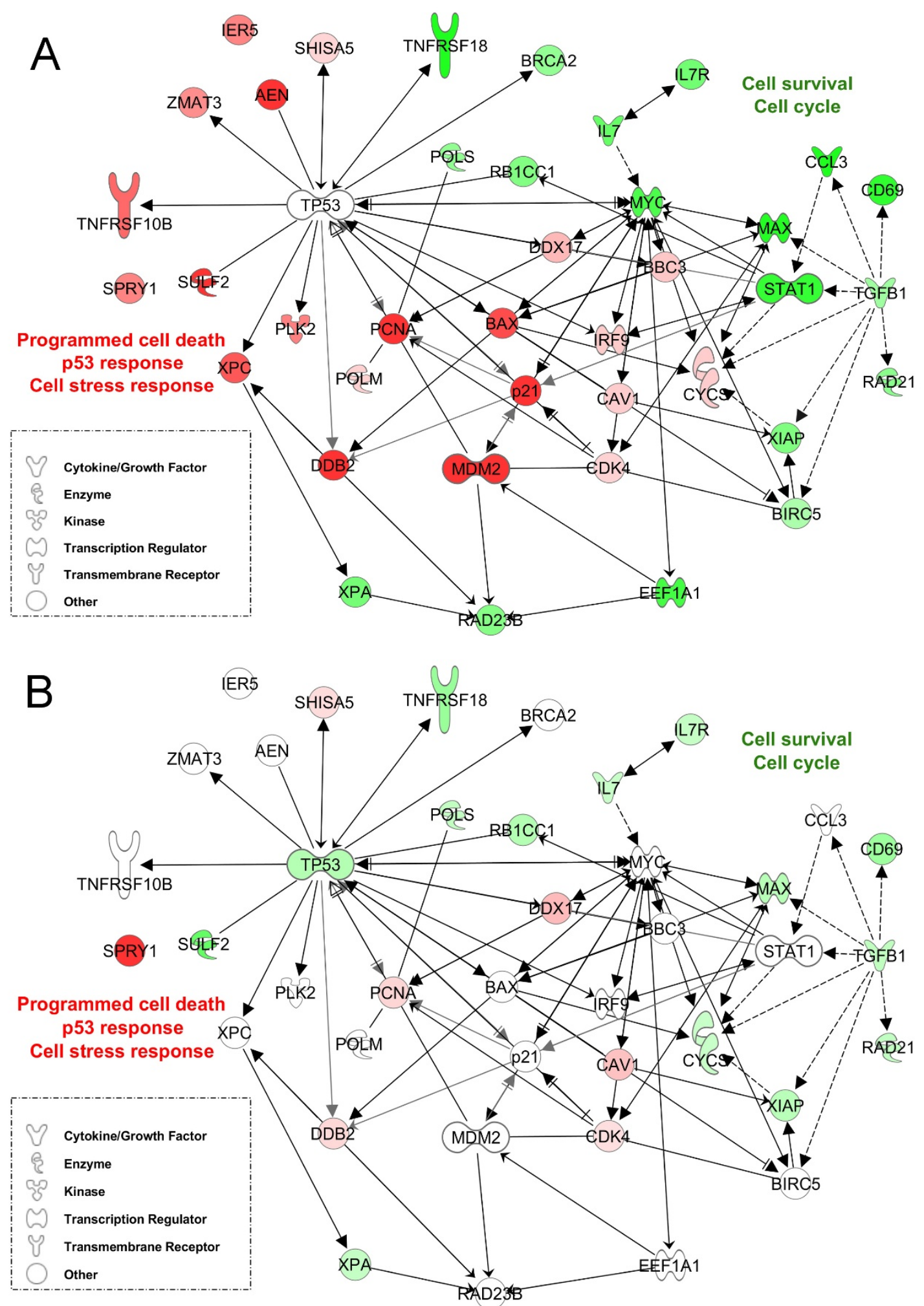

Figure 1 Molecular interaction network of fludarabine-regulated genes in cells of sensitive CLL patients in vivo. A group of genes highly regulated by fludarabine in sensitive patients (following a $24 \mathrm{~h}$ exposure in vivo) was clustered in a network around the transcription regulators TP53 and MYC using the Ingenuity Pathway Analysis software (IPA 8.0, database Nov 2009). $\boldsymbol{A}$, Gene expression values obtained from sensitive patients were overlaid on the network. $\boldsymbol{B}$. Gene expression values obtained from resistant patients were overlaid on the network. 

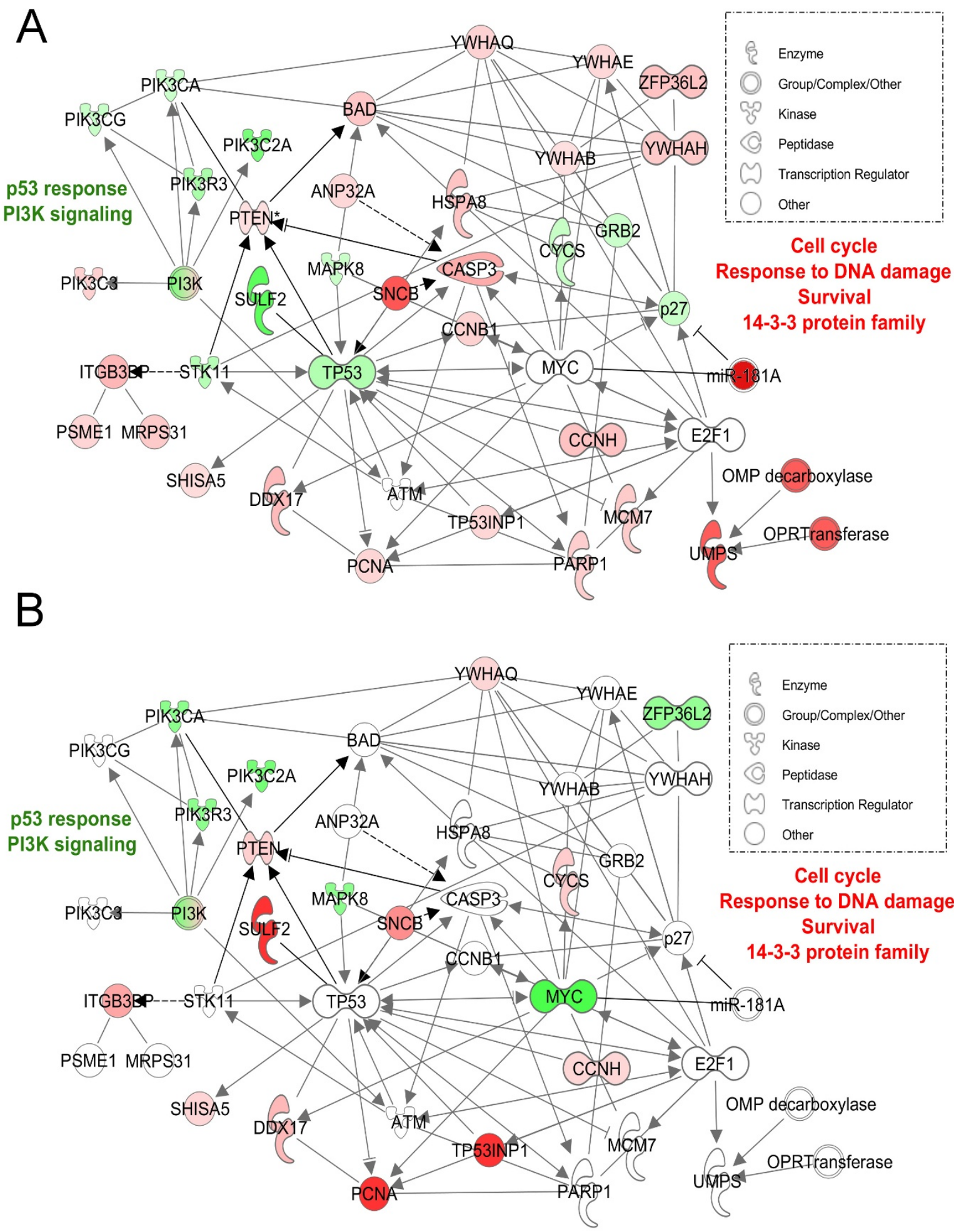

Figure 2 Molecular interaction network of fludarabine-regulated genes in cells of resistant CLL patients in vivo. A group of genes highly regulated by fludarabine in resistant patients (following a 24h exposure in vivo) was clustered in a network around the transcription regulators TP53 and MYC using the Ingenuity Pathway Analysis software (IPA 8.0, database Nov 2009). $\boldsymbol{A}$. Gene expression values obtained from resistant patients were overlaid on the network. $\boldsymbol{B}$. Gene expression values obtained from sensitive patients were overlaid on the network. 
was performed by SAM two-class analysis followed by unsupervised Pearson hierarchical clustering, revealing dramatic differences in the patterns of gene expression induced by the drug. As shown in Fig. 3, a set of 537 genes was significantly differentially regulated between cells of resistant and sensitive patients after $24 \mathrm{~h}$ of fludarabine treatment. The genes identified by SAM analysis can be found in the Additional file 6. Among these genes, 207 were over-expressed in resistant while repressed in cells of sensitive patients. Conversely, 330 genes were induced in sensitive while repressed in cells of resistant patients. These genes were classified by gene sets and biological functions with the GSEA algorithm. The genes up-regulated in B cells of sensitive patients were mainly involved in p53 signaling, DNA damage response, DNA repair, cell death, and cell cycle (Table 2). These functions were appreciably different from those represented in resistant patients in whom the majority of genes were implicated in the control of lymphocyte proliferation, cell growth and survival, DNA replication and repair, and functions of mature lymphocytes. Gene sets also contained responses mediated by $M Y C, E G R 2$, and $A P C$ transcription factors.

A related analysis identified 316 and 352 genes differentially regulated after two and nine days of treatment, respectively, representing biological functions very similar to those regulated after one day of treatment (data not shown).

\section{Cytotoxicity of fludarabine on CLL samples in vitro}

As a first step to validate in vitro some of the candidate marker genes identified above, we carried out cytotoxicity assays on cells from a cohort of CLL patients $(\mathrm{N}=21)$ with the aim to identify fludarabine-sensitive and -resistant cells. The definition of resistance to fludarabine in vitro is still a matter of debate; figures have been proposed that range from $20 \%$ of cell death following a $24-\mathrm{h}$ exposure to $1 \mu \mathrm{M}$ fludarabine [21] to an $\mathrm{IC}_{50}$ of $10 \mu \mathrm{M}$ after $72 \mathrm{~h}$ of treatment [22], and no consensus exists about the dose and time of treatment for in vitro studies. In our experiments, cytotoxicity was measured $48 \mathrm{~h}$ after exposure to fludarabine $(0-10 \mu \mathrm{M})$ and resistance was defined using a threshold cut-off based on the response obtained with all 21 samples. Thus, although we observed a wide distribution of responses to the treatment among patients, two groups could be clearly identified, and patients displaying an $\mathrm{IC}_{50}>7 \mu \mathrm{M}$ after $48 \mathrm{~h}$ of treatment in vitro were considered resistant (Additional file 7). Sixteen over twenty-one $(76.2 \%)$ CLL patients were identified as sensitive to fludarabine in vitro as the inhibitory concentration $\left(\mathrm{IC}_{50}\right)$ was lower or equal to $4 \mu \mathrm{M}$, which is very close to maximum dose achievable in clinics (4.5 $\mu \mathrm{M},[14])$. Five patients were classified as resistant $\left(\mathrm{IC}_{50}>\right.$ $7 \mu \mathrm{M}$ ), of which four had an $\mathrm{IC}_{50}$ greater than $10 \mu \mathrm{M}$.

We then used these two groups of cells to assess the expression of our candidate marker genes and miRNAs (see below) in vitro.

\section{Validation of gene and miRNA markers of cell resistance to fludarabine}

Microarray data were first validated by RT-qPCR in samples CLL-1 to -6 . Twenty genes with various intensities of expression are presented in Fig. 4. Although some discrepancies of intensity were observed, overall gene expression profiles assessed by qRT-PCR after $24 \mathrm{~h}$ of treatment with fludarabine were consistent with cDNA microarray data. Interestingly, when $\mathrm{qPCR}$ were performed to validate microarray data, we observed that the baseline expression of several genes greatly differed between CLL patients before treatment. Consistent with our previous observations, lower levels of transcripts of genes involved in early DNA damage detection and $p 53$ signaling were observed in resistant compared to sensitive patients (Table 3). Transcripts of other genes implicated in DNA repair and proliferation were in contrast more abundant. Interestingly, MYC and SULF2 transcripts were identified as strongly over-represented in B cells of patients CLL-3R and -6R resistant to fludarabine in vivo (20-34 and 72-157 fold, respectively). This observation was confirmed on a larger cohort of CLL patients treated with fludarabine in vivo $(\mathrm{N}=18$, Fig. $5 \mathrm{~A})$ or in vitro $(\mathrm{N}=21$, Fig. $5 \mathrm{~B})$ with both genes being significantly over-expressed in samples of resistant patients obtained before treatment $(\mathrm{p}<0.05)$.

Three miRNAs, miR-29a, miR-181a, and miR-221, have been shown to be regulated in CLL [8] and play important regulatory roles in oncogenesis and cell cycle regulation [23,24]. In addition, miR-29a and miR-181 are transcriptional targets of MYC family members which repress miR-29a [25] but induce miR-181a transcription [26]. This prompted us to also investigate miRNA expression in fludarabine-sensitive and resistant cells. We found that miR-181a and miR-221 were strongly over-represented in cells of resistant patients $(\mathrm{p}=0.015$ and $\mathrm{p}=$ 0.05 ), and that miR-29a was significantly down-regulated in patients resistant in vitro $(\mathrm{p}=0.026)$ (Fig. 5). Other miRNAs (miR-34a, miR-150*, and let-7e) were also repressed but not significantly ( $p>0.05$, data not shown).

In summary, we showed in cells of CLL patients resistant to fludarabine an over-expression of MYC, SULF2, miR-181a, and miR-221 together with a decrease in miR29a level. 
Table 2: Gene set enrichment analysis (GSEA) of CLL B cells from fludarabine-sensitive and -resistant patients

\begin{tabular}{|c|c|c|c|c|}
\hline Function/Pathway & $\begin{array}{l}\text { Gene sets enriched in sensitive } \\
\text { patients }\end{array}$ & Size & NES & NOM p-val \\
\hline \multirow[t]{7}{*}{ p53 response } & STRESS_ARSENIC_SPECIFIC_UP & 6 & 1.76 & 0.002 \\
\hline & P53PATHWAY & 6 & 1.61 & 0.004 \\
\hline & HSA04115_P53_SIGNALING_PATHWAY & 13 & 1.62 & 0.006 \\
\hline & P53GENES_ALL & 9 & 1.53 & 0.021 \\
\hline & P53_BRCA1_UP & 5 & 1.50 & 0.030 \\
\hline & STRESS_P53_SPECIFIC_UP & 5 & 1.44 & 0.031 \\
\hline & KANNAN_P53_UP & 9 & 1.51 & 0.032 \\
\hline \multirow[t]{3}{*}{ DNA damage response } & DNA_DAMAGE_SIGNALING & 13 & 1.69 & 0.008 \\
\hline & UVC_TTD-XPCS_COMMON_DN & 8 & 1.69 & 0.014 \\
\hline & CIS_XPC_DN & 10 & 1.73 & 0.017 \\
\hline $\begin{array}{l}\text { DNA repair, cell cycle, } \\
\text { apoptosis }\end{array}$ & BLEO_HUMAN_LYMPH_HIGH_4HRS_UP & 9 & 1.59 & 0.028 \\
\hline BAFF/APRIL receptor & MOREAUX_TACI_HI_VS_LOW_UP & 8 & 1.45 & 0.023 \\
\hline \multirow{2}{*}{$\begin{array}{l}\text { hTERT-regulated } \\
\text { genes }\end{array}$} & SMITH_HTERT_DN & 5 & 1.57 & 0.028 \\
\hline & ROTH_HTERT_DIFF & 7 & 1.48 & 0.049 \\
\hline NF-KB signaling & HINATA_NFKB_UP & 6 & 1.53 & 0.032 \\
\hline \multirow[t]{3}{*}{ Cell death } & APOPTOSIS & 6 & 1.55 & 0.034 \\
\hline & BRENTANI_DEATH & 6 & 1.55 & 0.034 \\
\hline & APOPTOSIS_GENMAPP & 5 & 1.56 & 0.035 \\
\hline \multirow[t]{3}{*}{ Cell cycle } & CELL_CYCLE_KEGG & 6 & 1.52 & 0.044 \\
\hline & CELL_CYCLE & 6 & 1.52 & 0.044 \\
\hline & TAKEDA_NUP8_HOXA9_16D_DN & 11 & 1.43 & 0.045 \\
\hline Function/Pathway & $\begin{array}{c}\text { Gene sets enriched in resistant } \\
\text { patients }\end{array}$ & Size & NES & NOM p-val \\
\hline $\begin{array}{l}\text { Tlymphocyte } \\
\text { proliferation }\end{array}$ & GOLDRATH_HP & 14 & 1.61 & 0.008 \\
\hline EGR2-regulated genes & LE_MYELIN_UP & 6 & 1.58 & 0.009 \\
\hline $\begin{array}{l}\text { Genes involved in } \\
\text { cholera infection }\end{array}$ & HSA05110_CHOLERA_INFECTION & 5 & 1.63 & 0.023 \\
\hline $\begin{array}{l}\text { Myeloma cell growth } \\
\text { and survival }\end{array}$ & CHAUHAN_2ME2 & 5 & 1.50 & 0.042 \\
\hline $\begin{array}{l}\text { DNA and RNA } \\
\text { metabolism }\end{array}$ & WERNER_FIBRO_DN & 5 & 1.45 & 0.059 \\
\hline $\begin{array}{l}\text { p53 response, anti- } \\
\text { apoptosis, DNA repair }\end{array}$ & UVB_SCC_DN & 6 & 1.39 & 0.086 \\
\hline Myc-regulated genes & MYC_ONCOGENIC_SIGNATURE & 8 & 1.37 & 0.061 \\
\hline $\begin{array}{l}\text { Functions of mature T } \\
\text { lymphocytes }\end{array}$ & LEE_TCELLS2_UP & 46 & 1.27 & 0.084 \\
\hline $\begin{array}{l}\text { Hematopoeitic stem } \\
\text { cell genes }\end{array}$ & BYSTRYKH_HSC_TRANS_GLOCUS & 29 & 1.38 & 0.070 \\
\hline APC-regulated genes & SANSOM_APC_LOSS5_UP & 10 & 1.47 & 0.084 \\
\hline
\end{tabular}

NES Normalized Enrichment Score, NOM p-val Nominal p-value 


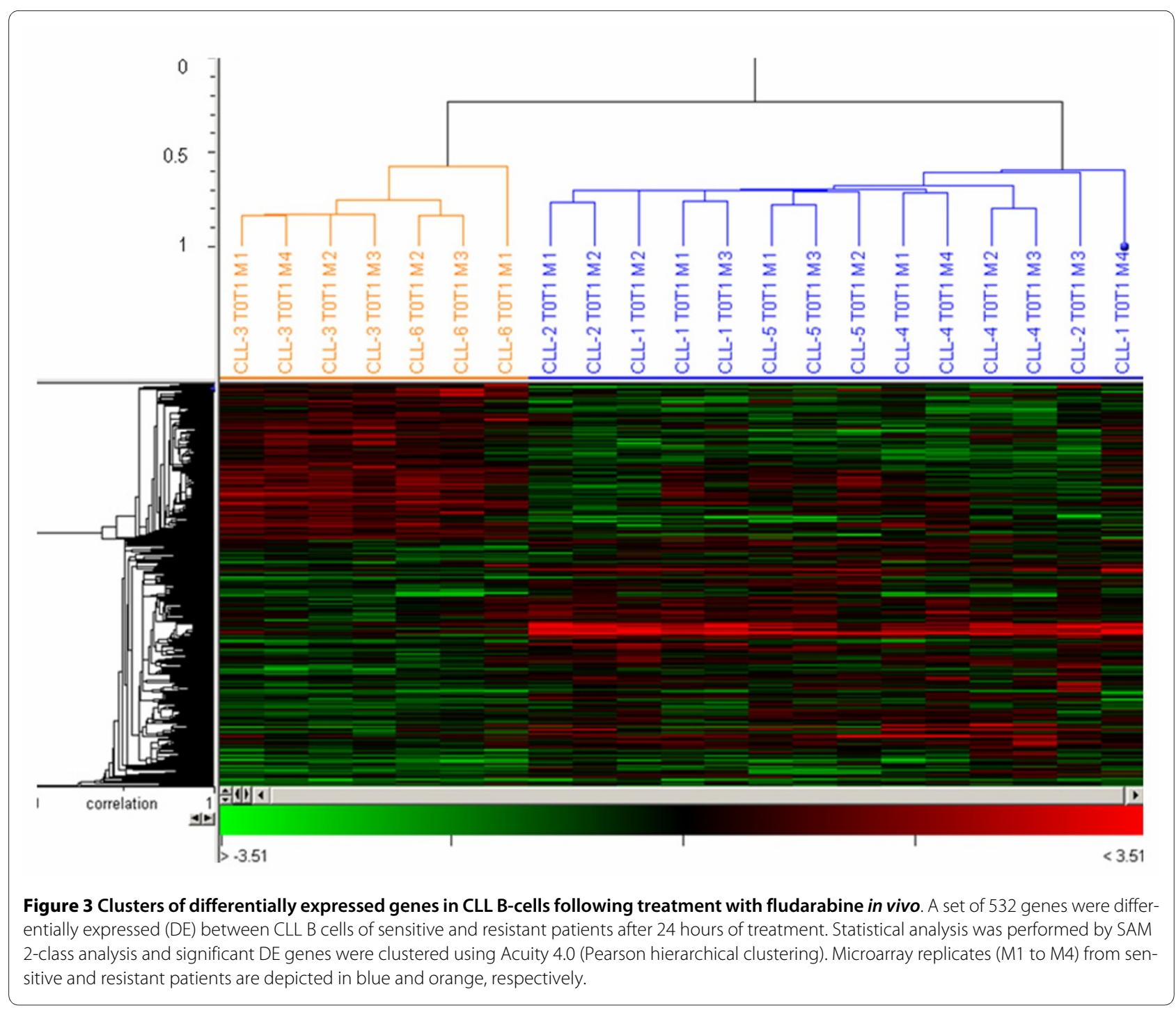

\section{Discussion}

The present study was first designed to improve our understanding of fludarabine-mediated killing of CLL cells in vivo. The response of cellular emergency mechanisms to DNA damage includes the transcriptional activation of mediators regulating cell cycle, DNA repair or apoptosis. Here we observed in sensitive B cells a strong up-regulation of p53-target genes (Fig. 1A and Additional file 4); thus confirming the results of previous in vivo studies $[15,20]$. We also detected a marked increase in the level of CDK4, PLK2, and cyclin G1 and a down-regulation of the cdk-inhibitor $p 27$, suggesting regulatory roles of these genes after fludarabine treatment in cells undergoing apoptosis. Novel regulators identified in this study (Additional file 4), such as the p53-target exonuclease $A E N$, the ER-localized scotin SHISA5, the speckle-type POZ protein SPOP, the Polo-like kinase PLK3 and the apoptosome inducer $A N P 32 A$, are required for DNA deg- radation and ER stress during p53-dependent cell cycle arrest and apoptosis [27-31]. Finally, CASP2, which is involved in p53-mediated apoptosis [32], and its inducer $I T G B 3 B P$ were up-regulated too, further supporting the role of caspase- 2 in the mechanisms underlying the cytotoxicity of fludarabine [32].

Albeit delayed, partial cellular death and induction of apoptosis-related genes were observed in the monoclonal population of resistant patients. This suggests that fludarabine entered the cells and was efficiently activated to its phosphorylated form. Therefore we did not investigate the biochemical aspects of resistance but we focused on the molecular response of the resistant cells. While fludarabine is known to inhibit DNA repair, we observed an over-expression of genes related to cell cycle, growth and survival, and DNA and RNA metabolism suggesting that cellular maintenance mechanisms operate in lymphocytes from resistant patients (Table 2 and Additional file 


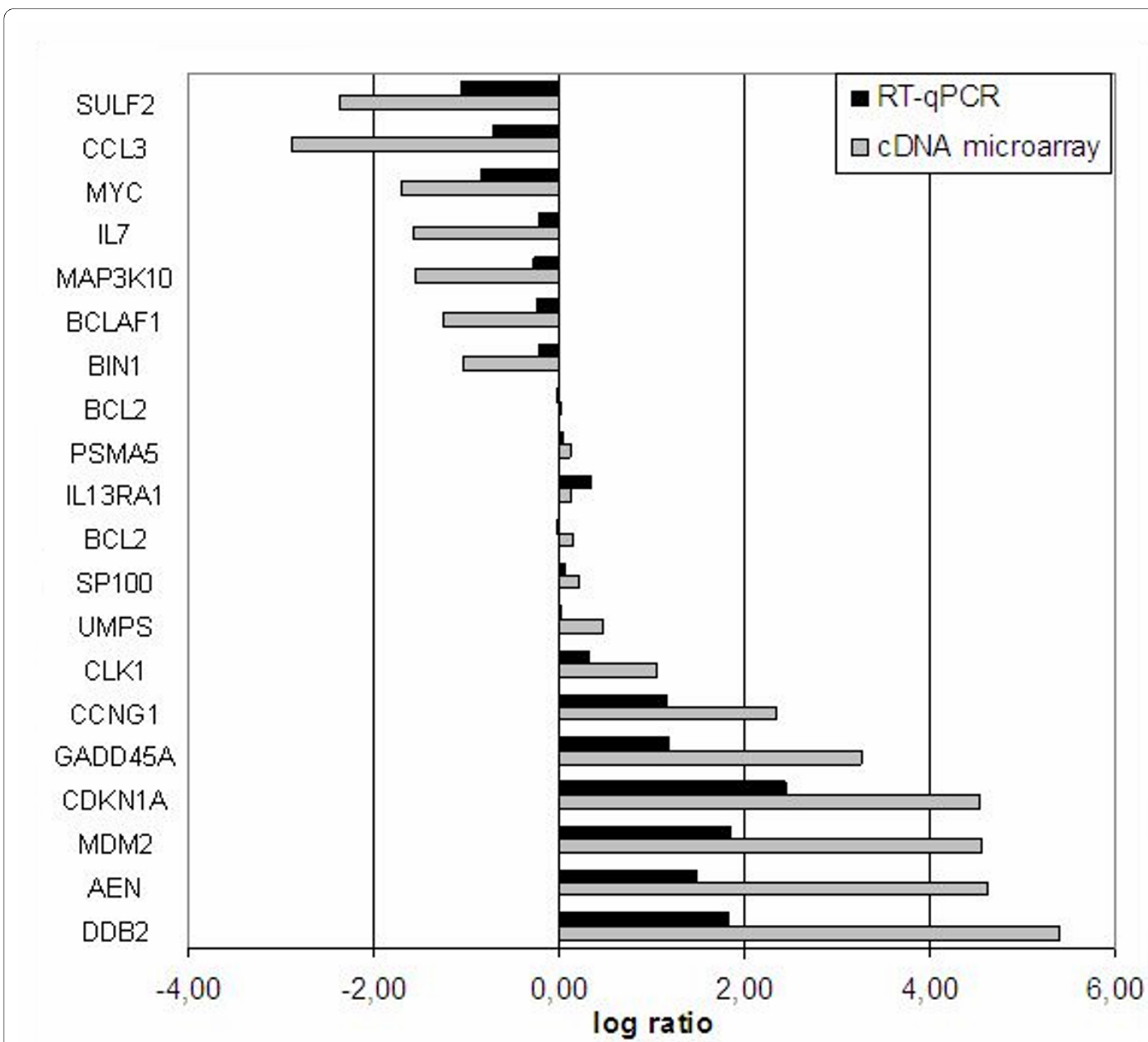

Figure 4 Validation of cDNA microarray gene expression data by RT-qPCR. Twenty differentially regulated genes identified in the microarray analysis were validated in the four CLL cases sensitive to fludarabine by RT-qPCR. B lymphocytes were isolated from blood of patients treated $24 \mathrm{~h}$ in vivo with fludarabine. Expression levels of the targets were normalized to both housekeeping genes and Ct values obtained before treatment were used as calibrators. See Methods for details.

5). This combination of factors could explain resistance as cells exhibit a reduced p53-response whilst displaying active DNA repair and proliferative responses. Factors negatively regulating $\mathrm{p} 53$ activation and increasing its degradation were also over-expressed (DDX17, SNCB, $S O D 1$, and TRIM28 [KAP1]). Interestingly, KAP1 protects cells from apoptosis in response to DNA damage [33] and represses $p 21$, GADD45A, Puma, Noxa, and Bax transcription, suggesting the repression of p53-dependent apoptotic effectors by KAP1-dependent mechanisms [34].
Recently, the availability of growth factors and angiogenesis have been recognized as important factors in CLL pathology [35] Our analysis of the pathways regulating cellular growth and proliferation revealed that transcripts of the 6-O endosulfatase SULF2, a novel p53-target gene [36], were differentially regulated in patients and dramatically more abundant in cells of resistant patients (Fig. 5). Contradictory functions of SULF2 have been reported in different models. Sulf2 has been shown to promote cell proliferation and migration by releasing VEGF and SDF-1 from heparin/heparin sulfate proteoglycans in the extracellular matrix [37]. The abundance of SULF2 transcripts, 
Table 3: Transcript levels of prognosis gene markers in B cells of CLL patients before treatment with fludarabine.

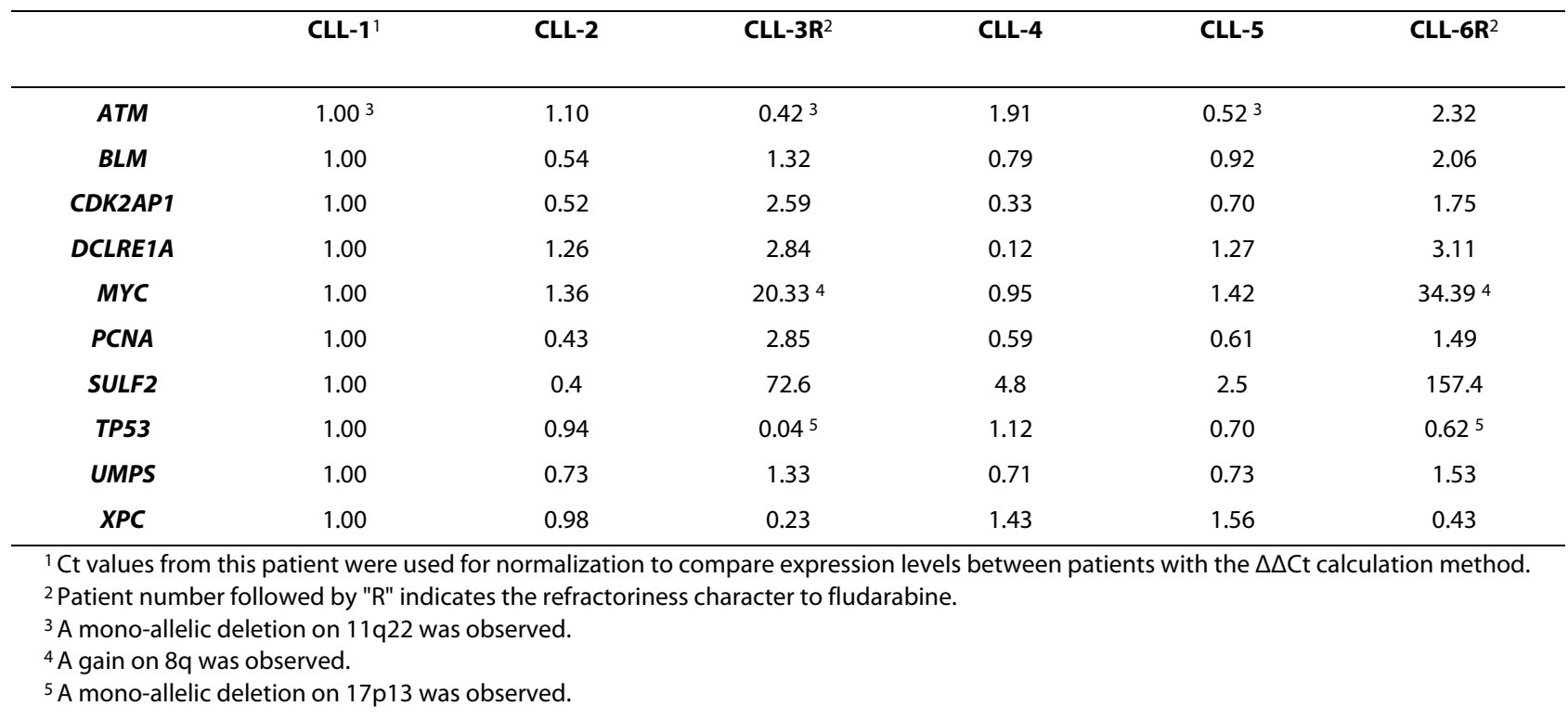

observed in this study in resistant patients prior to treatment, is in agreement with its proposed pro-angiogenic and oncogenic effects [38-40]. However fludarabine was found to increase the level of SULF2 mRNA in cells of sensitive patients only (Additional file 4). This finding also supports the notion that SULF2 is induced by antimetabolites [41] and can be a potent inhibitor of hematologic tumor growth in vivo [42]. We also detected a fludarabine-induced over-expression of the growth inhibitors $S P R Y 1$ and $C A V 1$ [43] mRNA in all conditions. Further investigations about tumor microenvironment will be required to understand the growth of malignant CLL cells in vivo.

Next we sought to investigate the genomic abnormalities associated with resistance. In addition to gains on chr7 (MDR genes) previously described [44] and a 9p deletion targeting SMARCA2 necessary for induction of p53 targets [45], we detected an important gain on the $15 \mathrm{q}$ arm. The presence of p53-cooperating genes on $15 \mathrm{q}$ reinforces the interest for this aberration in atypical CLL treated with DNA damage-inducing agents. In addition to these aberrations, we identified three isochromosomes in CLL cells leading to loss of heterozygosity. Thus isochromosomes may have clinical implications even though they are probably not primary lesions. As a consequence of the presence of the idic(8q), we observed a gain on $8 \mathrm{q}$ bearing the c-MYC oncogene in some resistant patients, which led us to investigate $M Y C$ expression in our samples. We observed the strong over-expression of $M Y C$ transcripts in CLL cells of resistant patients before treatment (Fig. 5A). This regulation was later confirmed in cells resistant to fludarabine in vitro, which also displayed higher levels of SULF2 (Fig. 5B).
We then considered Myc transcriptional targets and identified several differentially expressed genes and miRNAs that are direct targets of Myc in CLL B cells. An important conclusion of our work is that the Myc target gene network was up-regulated in cells that were resistant to fludarabine, whereas the p53 target gene network was down-regulated in these cells. For instance, over-expression of the Myc targets CDK4 and CCNB1 (cyclinB1)[46,47], which is suggestive of cell cycle progression, was observed in cells from our resistant patients. Interestingly, c-Myc and p53 have opposite effects on the regulation of cyclin $\mathrm{B} 1$, and induction of chromosomal instability by cyclin $\mathrm{B} 1$ over-expression was recently reported [47]. Likewise, Myc represses p53induced apoptosis in leukemia cells and selectively prevents p53 target gene transcriptional activation $[48,49]$. Differentially expressed Myc targets also included miRNAs. Thus, miR-29a and miR-181a are both confirmed transcriptional targets of $M Y C$ family members which repress miR-29a [25] but induce miR-181a transcription [26]. Interestingly, miR-181a and miR-221 were strongly over-expressed in the cells of resistant patients (Fig. $5 \mathrm{C}$ and D), confirming a previous association of miR-181a and miR-221 with poor prognosis [8] but contradicting another report that low miR-181a expression levels are associated with disease progression [9]. High levels of miR-181a and miR-221 also point to cell cycle progression as both miRNAs repress CDKN1B (p27) expression in hematologic diseases [23,50] and p27 was also found down-regulated in resistant cells (Additional file 5). Notably, miR-181a also targets phosphatases that modulate the activity of signaling kinases such as Zap-70 [51]; thus reinforcing the interest for this miRNA in CLL research. 


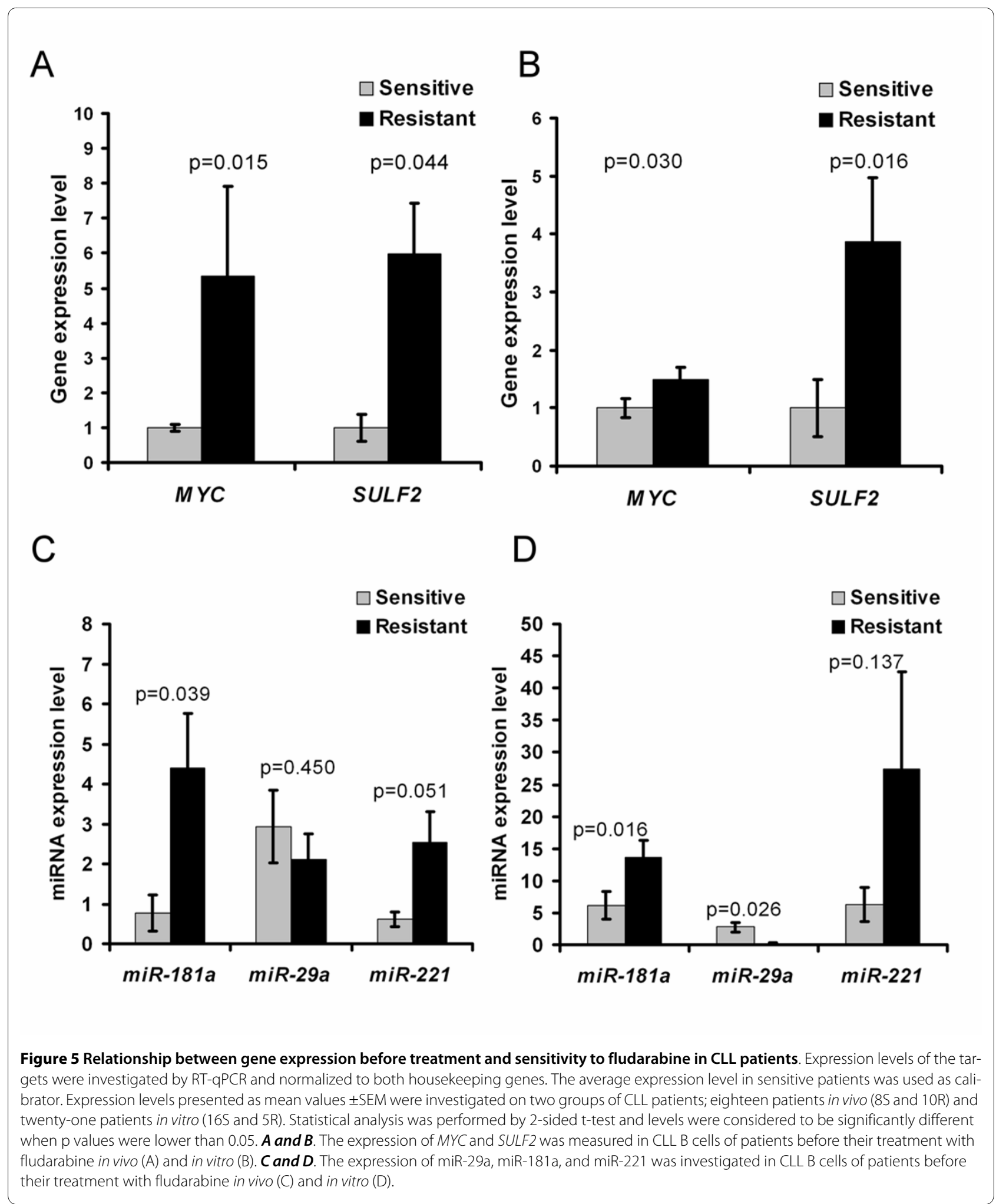

We also noticed that miR-29a was down-regulated in cells of resistant patients. In CLL, miR-29a levels have been reported to inversely correlate with TCL1 oncogene expression [24]. Studies using other cellular models indi- cate that miR-29a can activate p53 and induce apoptosis in a p53-dependent manner [52]. Our observation that the levels of miR-29a are lower in resistant patients is in agreement with these previous findings and suggests the 
importance of this regulation in aggressive CLL cases. Taken together, our data therefore underline the crucial and opposite role of the Myc and p53 gene regulatory networks in determining the cell response to fludarabine in CLL. Furthermore they underline the attraction of using Myc inhibition as an approach for improving CLL therapy. Amplification of Myc (i(8q)) in some CLL cases [53] reinforces this notion [54].

\section{Conclusions}

Although a recent report reinforces the prominent role of TP53 mutation as a prognosis tool for CLL [55], our work lends supports to other studies which have challenged the prognostic value of aberrations in master regulators such as ATM and TP53 [56,57]. Furthermore, our research considerably extends previous studies by identifying the oncogene MYC as over-expressed in B cells of CLL patients resistant to fludarabine in vivo and in vitro, and establishing the aberrant regulation of $M y c$-transcriptional target genes and miRNAs in these patients. Our data therefore support the importance of MYC in CLL pathology and its association with poor prognosis, as suggested by cytogenetic analyses [58]. They also underline the importance of the tumor microenvironment in the progression of CLL in vivo. Furthermore our work leads us to propose that the expression levels of MYC, SULF2, miR-29a, miR-181a and miR-221a measured in CLL patients could be of interest during clinical trials and may help to predict the chemo-refractory character of patients. Finally, Myc inhibition may be of high value in the treatment of poor prognosis CLL patients.

\section{Additional material}

Additional file 1 Clinical characteristics of B-CLL patients. Data concerning CLL patients treated in vivo and used in the study were gathered at sample collection (gender, age, stage, previous treatments and lymphocyte counts), obtained after blood processing and analysis (cytogenetics) or during the clinical follow-up of the patients (time to progression). Genomic abnormalities were detected by CGH array and FISH in B cells of CLL patients.

Additional file 2 Accumulation of genomic abnormalities in CLL B cells resistant to fludarabine. (A) FISH analysis confirmed the $15 q 22$ and 17q21 gains without any fusion. Green signal: RARa locus; red signal: PML locus. (B) Monoallelic 17p13 deletion (p53) due to isochromosome 17 in $92 \%$ of cells and chromosome 12 trisomy together with p53 deletion present in $7.5 \%$ of cells. Green signal: 12cen; red signal: TP53 locus. (C) Monoallelic 13q14 deletion in $90 \%$ of cells. Green signal: 13 qter; red signal: $13 q 14$ region. (D) Presence of $I G H-B C L 1$ fusion confirming the $t(11 ; 14)$. Green signal: IGH locus; red signal: BCL1 locus. Nuclei were counterstained with 4,6diamino-2-phenylindole (DAPI). Pictures are representative of CLL-3R and $6 \mathrm{R}$ resistant patients.

Additional file 3 Profiles of chromosomes 3, 8, 15, and 17 obtained by CGH-array analysis. Chromosome profiles were obtained after hybridization of blood B cells DNA. Similar aberrations were observed on blood B cells from resistant patients. (A) The graphical view (CGH analytics, Agilent) of isochromosome idic(3)(p12) was obtained from patient CLL-3R. (B-D) The $\operatorname{idic}(8)(p 12)$, the gain on chromosome 15, and the idic(17)(p12) were obtained from patient CLL-6R.
Additional file 4 Level of selected differentially expressed genes in CLL $B$ cells of sensitive patients following treatment with fludarabine in vivo. Gene expression profiling of B cells from CLL patients sensitive to fludarabine indicated the regulation of genes involved in the regulation of cell death, cell cycle and in the response to DNA damage. Fold change of selected genes are presented at different time points.

Additional file $\mathbf{5}$ Level of selected differentially expressed genes in CLL B cells of resistant patients following treatment with fludarabine in vivo. Gene expression profiling of B cells from CLL patients resistant to fludarabine indicated the regulation of genes involved in the regulation of DNA repair, cell growth and proliferation and cell death. Fold change of selected genes are presented at different time points.

Additional file 6 SAM analysis of regulated genes in B cells of resistant and sensitive CLL patients. Genes up-regulated in cells of resistant and sensitive CLL patients were identified after $24 \mathrm{~h}$ of treatment with fludarabine in vivo. The gene expression profiles from both groups were directly compared by a SAM 2-class analysis (unpaired, 100 permutations). The false discovery rate (FDR) was set at $5 \%$ and only significant genes were exported. The score $d$ denotes the standardized change in expression.

Additional file 7 Cytotoxic effect of fludarabine on CLL cells in vitro. The cytotoxicity of fludarabine $(0-10 \mu \mathrm{M})$ was examined on cells of CLL patients $(\mathrm{N}=21)$ after $48 \mathrm{~h}$ of treatment. Patients exhibiting an $\mathrm{IC}_{50}$ greater than $7 \mu \mathrm{M}$ after $48 \mathrm{~h}$ of treatment with fludarabine were considered to be resistant $(\mathrm{N}=5)$. When the $\mathrm{IC}_{50}$ was greater than $10 \mu \mathrm{M}$, the value was set at $10 \mu \mathrm{M}$.

\section{Competing interests}

The authors declare that they have no competing interests.

\section{Authors' contributions}

EM designed the study, performed research, analyzed data and wrote the paper. VP, LV, and EVD designed the study and wrote the paper. HAP performed cytogenetic analysis. TW performed sequencing and data analysis. VEK, NA, $\mathrm{KVM}, \mathrm{BL}$, and $\mathrm{FB}$ performed research and analyzed data. AM performed data mining analyses. $P C L, A D, C D, F R$ and $G B$ recruited patients, obtained written consents, and collected clinical data. All authors have read and approved the final manuscript.

\section{Acknowledgements}

This work was supported by grants from the Télévie $N^{\circ} 7.4552 .05$ to EM and BL and $N^{\circ} 7.4556 .05$ to VEK and KVM. The authors thank Maria Pires-Pacheco and Manon Bosseler for their technical assistance and Dr Petr Nazarov and Dr Mikalaï Yatskou (Microarray Center, CRP-Santé) for the statistical evaluation of the quality of microarrays. We are grateful to all CLL patients who donated blood for this study.

\section{Author Details}

${ }^{1}$ Laboratory of Experimental Hemato-Oncology, CRP-Santé, Luxembourg, Luxembourg, ${ }^{2}$ Microarray Center, CRP-Santé, Luxembourg, Luxembourg, ${ }^{3}$ Human Molecular Genetics, Cliniques universitaires saint-Luc/de Duve Institute/Université Catholique de Louvain, Brussels, Belgium, ${ }^{4}$ Société pour la Recherche contre le Cancer et les Maladies du Sang, Luxembourg, Luxembourg, 5 Hematology Department, University Hospital, Reims, France and ${ }^{6}$ Centre Hospitalier de Luxembourg, Luxembourg, Luxembourg

Received: 9 September 2009 Accepted: 20 May 2010

Published: 20 May 2010

\section{References}

1. Haferlach C, Dicker F, Schnittger S, Kern W, Haferlach T: Comprehensive genetic characterization of CLL: a study on 506 cases analysed with chromosome banding analysis, interphase $\mathrm{FISH}, \operatorname{lgV}(\mathrm{H})$ status and immunophenotyping. Leukemia 2007, 21:2442-2451.

2. Pettitt AR, Clarke AR, Cawley JC, Griffiths SD: Purine analogues kill resting lymphocytes by p53-dependent and -independent mechanisms. $\mathrm{Br} \mathrm{J}$ Haematol 1999, 105:986-988.

3. Parker WB, Bapat AR, Shen JX, Townsend AJ, Cheng YC: Interaction of 2halogenated dATP analogs $(\mathrm{F}, \mathrm{Cl}$, and $\mathrm{Br})$ with human DNA polymerases, DNA primase, and ribonucleotide reductase. Mol Pharmacol 1988, 34:485-491. 
4. Genini D, Adachi S, Chao Q, Rose DW, Carrera CJ, Cottam HB, Carson DA, Leoni LM: Deoxyadenosine analogs induce programmed cell death in chronic lymphocytic leukemia cells by damaging the DNA and by directly affecting the mitochondria. Blood 2000, 96:3537-3543.

5. Sandoval A, Consoli U, Plunkett W: Fludarabine-mediated inhibition of nucleotide excision repair induces apoptosis in quiescent human lymphocytes. Clin Cancer Res 1996, 2:1731-1741.

6. Ryan KM, Phillips AC, Vousden KH: Regulation and function of the p53 tumor suppressor protein. Curr Opin Cell Biol 2001, 13:332-337.

7. Zenz T, Mohr J, Eldering E, Kater AP, Buhler A, Kienle D, Winkler D, Durig J, van Oers $\mathrm{MH}$, Mertens $\mathrm{D}$, et al:: miR-34a as part of the resistance network in chronic lymphocytic leukemia. Blood 2009, 113:3801-3808.

8. Calin GA, Ferracin M, Cimmino A, Di Leva G, Shimizu M, Wojcik SE, lorio MV, Visone R, Sever NI, Fabbri M, et al:: A MicroRNA signature associated with prognosis and progression in chronic lymphocytic leukemia. $N$ Engl J Med 2005, 353:1793-1801.

9. Visone R, Rassenti LZ, Veronese A, Taccioli C, Costinean S, Aguda BD Volinia S, Ferracin M, Palatini J, Balatti V, et al:: Karyotype specific microRNA signature in chronic lymphocytic leukemia. Blood 2009, 114:3872-3879.

10. Zanette DL, Rivadavia F, Molfetta GA, Barbuzano FG, Proto-Siqueira R, Silva-Jr WA, Falcao RP, Zago MA: miRNA expression profiles in chronic lymphocytic and acute lymphocytic leukemia. Braz J Med Biol Res 2007, 40:1435-1440

11. Keating MJ, Kantarjian H, Talpaz M, Redman J, Koller C, Barlogie B, Velasquez W, Plunkett W, Freireich EJ, McCredie KB: Fludarabine: a new agent with major activity against chronic lymphocytic leukemia. Blood 1989, 74:19-25.

12. Bosanquet AG, Richards SM, Wade R, Else M, Matutes E, Dyer MJ, Rassam SM, Durant J, Scadding SM, Raper SL, et al:: Drug cross-resistance and therapy-induced resistance in chronic lymphocytic leukaemia by an enhanced method of individualised tumour response testing. $\mathrm{Br} J$ Haematol 2009, 146:384-395.

13. Zenz T, Habe S, Denzel T, Mohr J, Winkler D, Buhler A, Sarno A, Groner S, Mertens D, Busch $R$, et al:: Detailed analysis of $p 53$ pathway defects in fludarabine-refractory chronic lymphocytic leukemia (CLL): dissecting the contribution of 17p deletion, TP53 mutation, p53-p21 dysfunction, and miR34a in a prospective clinical trial. Blood 2009, 114:2589-2597.

14. Li L, Keating MJ, Plunkett W, Yang LY: Fludarabine-mediated repair inhibition of cisplatin-induced DNA lesions in human chronic myelogenous leukemia-blast crisis $\mathrm{K} 562$ cells: induction of synergistic cytotoxicity independent of reversal of apoptosis resistance. Mol Pharmacol 1997, 52:798-806.

15. Rosenwald A, Chuang EY, Davis RE, Wiestner A, Alizadeh AA, Arthur DC, Mitchell JB, Marti GE, Fowler DH, Wilson WH, Staudt LM: Fludarabine treatment of patients with chronic lymphocytic leukemia induces a p53-dependent gene expression response. Blood 2004, 104:1428-1434.

16. Kerr MK, Churchill GA: Experimental design for gene expression microarrays. Biostatistics 2001, 2:183-201.

17. Yatskou M, Novikov E, Vetter G, Muller A, Barillot E, Vallar L, Friederich E: Advanced spot quality analysis in two-colour microarray experiments. BMC Res Notes 2008, 1:80.

18. Vandesompele J, De Preter K, Pattyn F, Poppe B, Van Roy N, De Paepe A Speleman F: Accurate normalization of real-time quantitative RT-PCR data by geometric averaging of multiple internal control genes. Genome Biol 2002, 3:RESEARCH0034.

19. Stamatopoulos B, Meuleman N, Haibe-Kains B, Duvillier H, Massy M, Martiat $P$, Bron D, Lagneaux L: Quantification of ZAP70 mRNA in B cells by real-time $P C R$ is a powerful prognostic factor in chronic lymphocytic leukemia. Clin Chem 2007, 53:1757-1766.

20. de Viron E, Knoops L, Connerotte T, Smal C, Michaux L, Saussoy P, Vannuffel $P$, Beert $E$, Vekemans MC, Hermans C, et al:: Impaired upregulation of polo-like kinase 2 in B-cell chronic lymphocytic leukaemia lymphocytes resistant to fludarabine and 2chlorodeoxyadenosine: a potential marker of defective damage response. Br J Haematol 2009, 147:641-652.

21. Pedersen IM, Kitada S, Schimmer A, Kim Y, Zapata JM, Charboneau L, Rassenti L, Andreeff M, Bennett F, Sporn MB, et al:: The triterpenoid CDDO induces apoptosis in refractory CLL B cells. Blood 2002, 100:2965-2972.

22. Trachootham D, Zhang H, Zhang W, Feng L, Du M, Zhou Y, Chen Z, Pelicano $H_{1}$ Plunkett W, Wierda WG, et al. Effective elimination of fludarabine-resistant CLL cells by PEITC through a redox-mediated mechanism. Blood 2008, 112:1912-1922.

23. Frenquelli M, Muzio M, Scielzo C, Fazi C, Scarfo L, Rossi C, Ferrari G, Ghia P, Caligaris-Cappio F: MicroRNA and proliferation control in chronic lymphocytic leukemia: functional relationship between miR-221/222 cluster and p27. Blood 2010, 115:3949-3959.

24. Pekarsky Y, Santanam U, Cimmino A, Palamarchuk A, Efanov A, Maximov V, Volinia S, Alder H, Liu CG, Rassenti L, et al:: Tcl1 expression in chronic lymphocytic leukemia is regulated by miR-29 and miR-181. Cancer Res 2006, 66:11590-11593.

25. Chang TC, Yu D, Lee YS, Wentzel EA, Arking DE, West KM, Dang CV, Thomas-Tikhonenko A, Mendell JT: Widespread microRNA repression by Myc contributes to tumorigenesis. Nat Genet 2008, 40:43-50.

26. Mestdagh $P$, Van Vlierberghe P, De Weer A, Muth D, Westermann F, Speleman F, Vandesompele J: A novel and universal method for microRNA RT-qPCR data normalization. Genome Bio/ 2009, 10:R64

27. Bourdon JC, Renzing J, Robertson PL, Fernandes KN, Lane DP: Scotin, a novel p53-inducible proapoptotic protein located in the ER and the nuclear membrane. J Cell Biol 2002, 158:235-246

28. Jiang N, Wang X, Jhanwar-Uniyal M, Darzynkiewicz Z, Dai W: Polo box domain of Plk3 functions as a centrosome localization signal, overexpression of which causes mitotic arrest, cytokinesis defects, and apoptosis. J Biol Chem 2006, 281:10577-10582

29. Kawase T, Ichikawa H, Ohta T, Nozaki N, Tashiro F, Ohki R, Taya Y: p53 target gene AEN is a nuclear exonuclease required for p53-dependent apoptosis. Oncogene 2008, 27:3797-3810.

30. Kwon JE, La M, Oh KH, Oh YM, Kim GR, Seol JH, Baek SH, Chiba T, Tanaka K, Bang OS, et al:: BTB domain-containing speckle-type $\mathrm{POZ}$ protein (SPOP) serves as an adaptor of Daxx for ubiquitination by Cul3-based ubiquitin ligase. J Biol Chem 2006, 281:12664-12672.

31. Mazroui R, Di Marco S, Clair E, von Roretz C, Tenenbaum SA, Keene JD, Saleh M, Gallouzi IE: Caspase-mediated cleavage of HuR in the cytoplasm contributes to pp32/PHAP-I regulation of apoptosis. $\mathrm{J}$ Cell Biol 2008, 180:113-127.

32. Baptiste-Okoh N, Barsotti AM, Prives C: A role for caspase 2 and PIDD in the process of p53-mediated apoptosis. Proc Natl Acad Sci USA 2008, 105:1937-1942.

33. White DE, Negorev D, Peng H, Ivanov AV, Maul GG, Rauscher FJ: KAP1, a novel substrate for PIKK family members, colocalizes with numerous damage response factors at DNA lesions. Cancer Res 2006, 66:11594-11599.

34. Wang C, Ivanov A, Chen L, Fredericks WJ, Seto E, Rauscher FJ, Chen J: MDM2 interaction with nuclear corepressor KAP1 contributes to p53 inactivation. Embo J 2005, 24:3279-3290.

35. Maffei R, Martinelli S, Castelli I, Santachiara R, Zucchini P, Fontana M, Fiorcari S, Bonacorsi G, Ilariucci F, Torelli G, Marasca R: Increased angiogenesis induced by chronic lymphocytic leukemia $B$ cells is mediated by leukemia-derived Ang2 and VEGF. Leuk Res 2009, 34:312-321

36. Chau BN, Diaz RL, Saunders MA, Cheng C, Chang AN, Warrener P, Bradshaw J, Linsley PS, Cleary MA: Identification of SULF2 as a novel transcriptional target of $\mathrm{p} 53$ by use of integrated genomic analyses. Cancer Res 2009, 69:1368-1374.

37. Uchimura K, Morimoto-Tomita M, Bistrup A, Li J, Lyon M, Gallagher J, Werb Z, Rosen SD: HSulf-2, an extracellular endoglucosamine-6-sulfatase, selectively mobilizes heparin-bound growth factors and chemokines: effects on VEGF, FGF-1, and SDF-1. BMC Biochem 2006, 7:2

38. Morimoto-Tomita M, Uchimura K, Bistrup A, Lum DH, Egeblad M, Boudreau N, Werb Z, Rosen SD: Sulf-2, a proangiogenic heparan sulfate endosulfatase, is upregulated in breast cancer. Neoplasia 2005, 7:1001-1010.

39. Lai JP, Sandhu DS, Yu C, Han T, Moser CD, Jackson KK, Guerrero RB, Aderca I, Isomoto H, Garrity-Park MM, et al:: Sulfatase 2 up-regulates glypican 3, promotes fibroblast growth factor signaling, and decreases survival in hepatocellular carcinoma. Hepatology 2008, 47:1211-1222.

40. Lemjabbar-Alaoui $H$, van Zante A, Singer MS, Xue Q, Wang YQ, Tsay D, He $B$, Jablons DM, Rosen SD: Sulf-2, a heparan sulfate endosulfatase, promotes human lung carcinogenesis. Oncogene 2010, 29:635-646.

41. Adamsen BL, Kravik KL, Clausen OP, De Angelis PM: Apoptosis, cell cycle progression and gene expression in TP53-depleted HCT116 colon cancer cells in response to short-term 5-fluorouracil treatment. Int Oncol 2007, 31:1491-1500 
42. Dai Y, Yang Y, MacLeod V, Yue X, Rapraeger AC, Shriver Z, Venkataraman G, Sasisekharan R, Sanderson RD: HSulf-1 and HSulf-2 are potent inhibitors of myeloma tumor growth in vivo. J Biol Chem 2005, 280:40066-40073.

43. Cabrita MA, Jaggi F, Widjaja SP, Christofori G: A functional interaction between sprouty proteins and caveolin-1. J Biol Chem 2006, 281:29201-29212.

44. Friedenberg WR, Spencer SK, Musser C, Hogan TF, Rodvold KA, Rushing DA, Mazza JJ, Tewksbury DA, Marx JJ: Multi-drug resistance in chronic lymphocytic leukemia. Leuk Lymphoma 1999, 34:171-178.

45. Xu Y, Zhang J, Chen $X$ : The activity of $p 53$ is differentially regulated by Brm- and Brg1-containing SWI/SNF chromatin remodeling complexes. J Biol Chem 2007, 282:37429-37435.

46. Hermeking H, Rago C, Schuhmacher M, Li Q, Barrett JF, Obaya AJ, O'Connell BC, Mateyak MK, Tam W, Kohlhuber F, et al: Identification of CDK4 as a target of c-MYC. Proc Nat/ Acad Sci USA 2000, 97:2229-2234.

47. Yin XY, Grove L, Datta NS, Katula K, Long MW, Prochownik EV: Inverse regulation of cyclin B1 by c-Myc and p53 and induction of tetraploidy by cyclin B1 overexpression. Cancer Res 2001, 61:6487-6493.

48. Ceballos E, Munoz-Alonso MJ, Berwanger B, Acosta JC, Hernandez R, Krause M, Hartmann O, Eilers M, Leon J: Inhibitory effect of c-Myc on p53-induced apoptosis in leukemia cells. Microarray analysis reveals defective induction of p53 target genes and upregulation of chaperone genes. Oncogene 2005, 24:4559-4571.

49. Seoane J, Le HV, Massague J: Myc suppression of the p21 (Cip1) Cdk inhibitor influences the outcome of the p53 response to DNA damage. Nature 2002, 419:729-734.

50. Cuesta R, Martinez-Sanchez A, Gebauer F: miR-181a regulates capdependent translation of p27(kip1) mRNA in myeloid cells. Mol Cell Biol 2009, 29:2841-2851

51. Li QJ, Chau J, Ebert PJ, Sylvester G, Min H, Liu G, Braich R, Manoharan M, Soutschek J, Skare P, et al.: miR-181a is an intrinsic modulator of T cell sensitivity and selection. Cell 2007, 129:147-161.

52. Park SY, Lee JH, Ha M, Nam JW, Kim VN: miR-29 miRNAs activate $\mathrm{p} 53$ by targeting p85 alpha and CDC42. Nat Struct Mol Biol 2009, 16:23-29.

53. Forconi F, Rinaldi A, Kwee I, Sozzi E, Raspadori D, Rancoita PM, Scandurra M, Rossi D, Deambrogi C, Capello D, et al.: Genome-wide DNA analysis identifies recurrent imbalances predicting outcome in chronic lymphocytic leukaemia with 17p deletion. Br J Haematol 2008, 143:532-536.

54. Soucek L, Whitfield J, Martins CP, Finch AJ, Murphy DJ, Sodir NM, Karnezis AN, Swigart LB, Nasi S, Evan Gl: Modelling Myc inhibition as a cancer therapy. Nature 2008, 455:679-683.

55. Dicker F, Herholz H, Schnittger S, Nakao A, Patten N, Wu L, Kern W, Haferlach T, Haferlach C: The detection of TP53 mutations in chronic lymphocytic leukemia independently predicts rapid disease progression and is highly correlated with a complex aberrant karyotype. Leukemia 2009, 23:117-124.

56. Cejkova S, Rocnova L, Potesil D, Smardova J, Novakova V, Chumchalova J, Zezulkova D, Borsky M, Doubek M, Brychtova Y, et al:: Presence of heterozygous ATM deletion may not be critical in the primary response of chronic lymphocytic leukemia cells to fludarabine. Eur J Haematol 2009, 82:133-142.

57. Valganon M, Giraldo P, Agirre X, Larrayoz MJ, Rubio-Martinez A, RubioFelix D, Calasanz MJ, Odero MD: p53 Aberrations do not predict individual response to fludarabine in patients with B-cell chronic lymphocytic leukaemia in advanced stages Rai III/IV. Br J Haematol 2005, 129:53-59.

58. Huh YO, Lin Kl, Vega F, Schlette E, Yin CC, Keating MJ, Luthra R, Medeiros $\sqcup$, Abruzzo LV: MYC translocation in chronic lymphocytic leukaemia is associated with increased prolymphocytes and a poor prognosis. $\mathrm{Br} J$ Haematol 2008, 142:36-44.

\section{doi: 10.1186/1476-4598-9-115}

Cite this article as: Moussay et al., Determination of genes and microRNAs involved in the resistance to fludarabine in vivo in chronic lymphocytic leukemia Molecular Cancer 2010, 9:115

\section{Submit your next manuscript to BioMed Central} and take full advantage of:

- Convenient online submission

- Thorough peer review

- No space constraints or color figure charges

- Immediate publication on acceptance

- Inclusion in PubMed, CAS, Scopus and Google Scholar

- Research which is freely available for redistribution

Submit your manuscript at www.biomedcentral.com/submit
C) Biomed Central 